\title{
Malé zamyšlení nad jedním kalendářem
}

\author{
Vážení čtenáři,
}

předmluvu pro první číslo Českého finančního a účetního časopisu v tomto roce si dovolím věnovat malému zamyšlení nad jedním nástěnným kalendářem. Při příležitosti 125 . výročí svého založení rozeslala American Economic Association svým členům kalendář pokrývající období od ledna 2010 až do června 2011. Každý z těchto osmnácti měsíců je vždy zasvěcen jednomu slavnému jménu ekonomické vědy. Na první straně se nachází obrázek Adama Smithe, který přednáší svoji teorii mravních citů (rozpoznáno dle textu na tabuli), ${ }^{1}$ a jeho přednášce pozorně naslouchá sedmnáct posluchačů. Hned v první lavici sedí John Stuart Mill, George Stigler, Karl Marx a John Maynard Keynes, v další řadě se nachází Irving Fisher, Josef Alois Schumpeter, Friedrich von Hayek, David Ricardo, Léon Walras a Thomas Robert Malthus, zadní místa obsadili Francis Edgeworth, Thorstein Veblen, Alfred Marshall, John von Neumann a Richard Theodore Ely, trochu stranou pak sedí Joan Robinson a Milton Friedman.

Postavení skotského rodáka Adama Smithe (5.6.1723 - 17. 7. 1790) v roli učitele se zdá být neoddiskutovatelné. Ve svých hlavních dílech Teorie mravních citů a Pojednání o podstatě a původu bohatství národi̊ položil základy moderní ekonomické vědy, z kterých dosud těží současní badatelé na celém světě. Jeho následovníci rozvinuli jeho teorii v mnoha často velmi odlišných směrech.

Jako nejstarší žák vystupuje původně burzovní makléř z Londýna David Ricardo (18. 4. 1772 - 11. 9. 1823), kterému, když vyšla Smithova kniha o bohatství národů, bylo teprve 27 let, a do světa vědy přispěl hlavně teorií komparativních výhod popsanou v Zásadách politické ekonomie a zdanění. Z hlediska věku následuje hned za ním anglický ekonom a anglikánský pastor Thomas Robert Malthus (13.2.1776-23. 12. 1834), jenž v Eseji o principu populace nadnesl poněkud chmurné vyhlídky v budoucnosti pramenící podle jeho názoru $\mathrm{z}$ nedostatečné kontroly nad bídou, neřestmi a sexuálním sebeovládáním.

K dalším následovníkům patřil anglický politik, John Stuart Mill (20. 5. 1806 - 8. 5. 1873), zdůrazňující v Zásadách politické ekonomie současně nutnost existence sociální spravedlnosti a soukromého vlastnictví. Dostane-li člověk do svého vlastnictví třeba holou skálu, je schopen ji přeměnit svoji prací i v kvetoucí zahradu. Anglický ekonom, Alfred Marshall (26. 7. 1842 13. 7. 1924), rozpracoval teorii mezního užitku a přispěl napřr. cenovou elasticitou poptávky. Kniha Zásady ekonomie se stala oblíbenou učebnicí své doby. Irský rodák, Francis Edgeworth (8. 2. 1845 - 13. 2. 1926), obohatil teorii mimo jiné o indiferentní křivky, ale hlavně se zasloužil o rozvoj statistických nástrojů v ekonomii, o nichž pojednává v Matematické psychice. Eseji o aplikaci matematiky v mravních vědách. Anglické autory doplňuje John Maynard Keynes (5. 6. 1883 - 21. 4. 1946), jehož závěry vedly v mnoha zemích k zavedení státních zásahů během Velké hospodářské krize v 30. letech minulého století, jeho nejznámější dílo tvoří kniha Obecná teorie zaméstnanosti, úroku a peněz. Z Anglie pochází i jediná žena, jíž je v kalendáři věnováno zvláštní místo. Joan Robinson (31. 10. 1903 - 5. 8. 1983) rozpracovala v Akumulaci kapitálu keynesiánskou teorii.

Jedná se úvodní text z knihy Teorie mravnich citũ: At’ již je dovoleno pokládat člověka za jakkoli sobeckého, presto v jeho přirozenosti evidentně existuji určité principy, které zpưsobuji, že je zainteresován na osudu jiných lidí a že jejich štěstí je pro něj nezbytné, $i$ když z něj nemá nic jiného kromě radosti, že je jeho svědkem (str. 5 českého překladu této knihy vydaného Liberálním institutem v Praze v roce 2005). 
Francouzskou školu politické ekonomie zastupuje Léon Walras (16. 12. 1834 - 5. 1. 1910) využívající matematickou analýzu v Základech čisté ekonomiky k vytvoření modelu rozvinutí teorie všeobecné ekonomické rovnováhy.

Přítomen mezi žáky politické ekonomie je i německý rodák Karel Marx (5. 5. 1818 14. 3. 1883) kritizující kapitalismus a vykořist’ování dělníků v Kapitálu. Jeho dílo inspirovalo další osoby ke snaze svět změnit a následně stvořit spravedlivou beztř́ídní společnost. Všechny podobné pokusy však skončily nakonec s přesně opačným výsledkem. Další student, rakouský liberální ekonom Friedrich von Hayek (18. 3. 1899 - 23. 3. 1992), založil své dílo právě na ostré kritice komunistické ideologie, kterou výstižně nazývá Cestou do otroctví. Z původně německých autorů nebyl v seznamu opominut ani rodák z moravské obce Třešt', Josef Alois Schumpeter (8. 2. 1883 - 8. 1. 1950) zabývající se především Teorii ekonomického rozvoje. $\mathrm{Na}$ území Rakouska-Uherska se narodil i budapešt'ský rodák, John von Neumann (28. 12. 1903 - 8. 2. 1957), který společně s Oskarem Morgensternem zpracoval základy Teorie her a ekonomického chování.

Další studenty představují již zástupci americké ekonomické školy: Richard Theodore Ely (13.4. 1854 - 4. 10. 1953), první tajemník American Economic Association a autor Studie evoluce v průmyslové společnosti, Thorstein Veblen (30.7.1857 - 3. 8. 1929) zdůrazňující institucionální prvky v ekonomii a autor Teorie zahálčivé třídy, Irving Fisher (27. 2. 1867 29. 4. 1947) zabývající se Matematickými výzkumy v teorii hodnoty a cen, a proslavený svojí Teorii úroku. Z nositelů Nobelových cen za ekonomii se objevují jen dva vědci: George Stigler (17. 1. 1911 - 1. 12. 1991) věnující se studiu Teorie ekonomické regulace a Milton Friedman (31. 7. 1912 - 16. 11. 2006), představitel chicagské školy a tvưrce monetaristické teorie, kterou zpracoval v knize Monetární historie Spojených států napsané společně s Annou Jacobson Schwartz.

U většiny dní v roce jsou uvedena jména představitelů ekonomické vědy, kteří se v tento den narodili, příp. u dř́ve narozených osob byli pokřtěni. Celkem jde o reprezentativní výběr 392 ekonomů žijících $\mathrm{v}$ různé době, pocházejících z různých zemí a zabývajících se často různým vědeckým zaměřením. $V$ tomto výběru se nachází jak jména všeobecně známá, tak $\mathrm{i}$ jména spíše neznámá a dnes už v podstatě zapomenutá. Lze nalézt ovšem některá překvapení. V př́ípadě Vladimíra Iljiče Lenina si jen matně vzpomínám ze svých dřívějších studií, že v jeho sebraných spisech se občas objevily náznaky vědecké práce, ale přesto jeho zařazení mezi renomované vědce mi prŕliš nesedí. Ale největším překvapením se zdá být Rosa Luxembourg, která byla pro mne až dosud dřivějším režimem zprofanovanou představitelkou komunismu. Teprve tento kalendář mne donutil nahlédnout do jejího životopisu, a v něm lze nalézt i její spis o akumulaci kapitálu sepsaný v duchu marxistické ekonomie.

Největší počet jmen se objevuje v měsíci červenci (44), naopak nejméně v měsíci záríi (28). $\mathrm{Z}$ hlediska jednotlivých dní v roce vyhrává 26 . červenec, $\mathrm{v}$ tento den se narodilo celkem pět slavných ekonomických vědců. Vhodným dnem pro narození nového budoucího génia se ovšem zdá i 5. červen, kdy své narozeniny (resp. den svého křtu) mohl slavit jak Adam Smith tak i John Maynard Keynes.

Zastoupení žen v ekonomické vědě je bohužel spíše symbolické. V seznamu jich lze nalézt jen jedenáct. Vedle Joan Robinson a Rosy Luxembourg jsou to Irma Glicman Adelman, Susan Carleton Atley, Mary Joan Bowman, Katharine Coman, Anne Osborn Krueger, Margaret Gilpin Reid, Alice Mitchell Rivlin, Anna Jacobson Schwartz a Martha Beatrice Webb. 
Osm ekonomických vědců ve výběru se narodilo v sedmnáctém století, 31 v osmnáctém století, 148 v devatenáctém století a 205 ve století dvacátém. Nejstarším reprezentantem se stal anglický ekonom William Petty (27. 5. 1623 - 16. 12. 1687), tvůrce pracovní teorie hodnoty, naopak mladší generaci zastupuje francouzský badatel Emmanuel Saez (26.11.1972) zabývající se optimálním zdaněním.

Kalendář American Economic Association připomíná jména těch, kteří se zasloužili o rozvoj ekonomické vědy, těch osob, bez jejichž výzkumu, myšlenek, analýz, modelů, ale také omylů, by náš dnešní svět vypadal trochu jinak. Možná bez některých z nich by byl svět lepší, to jistě nelze vyloučit, ale spíše bychom dnes stáli před stejnými problémy, jež se podařilo již našim předchůdcům vyřešit.

\author{
prof. Ing. Petr Marek, CSc. \\ předseda redakční rady Českého finančního a účetního časopisu \\ a řešitel výzkumného záměru \\ Rozvoj účetní a finanční teorie \\ a její aplikace $v$ praxi z interdisciplinárního hlediska
}

